\title{
Erratum to: Etanercept (SB4): A Review in Autoimmune Inflammatory Diseases
}

\author{
Celeste B. Burness ${ }^{1} \cdot$ Sean T. Duggan ${ }^{1}$
}

Published online: 29 September 2016

(C) Springer International Publishing Switzerland 2016

\section{Erratum to: BioDrugs (2016) 30:371-378 \\ DOI 10.1007/s40259-016-0188-z}

Page 375, column 2, section 5, paragraph 3, lines 398-404: The following sentence, which previously read:

"At week 24, the incidence of injection-site reactions was comparable at week 52 [3.7\% of etanercept (SB4) recipients vs. $17.5 \%$ reference etanercept recipients] [18].”

\section{should read:}

"The incidence of injection-site reactions at week 52 [3.7\% of etanercept (SB4) recipients vs. $17.5 \%$ reference etanercept recipients] was consistent with that seen at week 24 [18]."

The online version of the original article can be found under doi:10.1007/s40259-016-0188-z.

\section{Celeste B. Burness}

demail@springer.com

1 Springer, Private Bag 65901, Mairangi Bay, 0754 Auckland, New Zealand 